\title{
Nomenclature for factors of the HLA system
}

\author{
Nomenclatura dos fatores do sistema HLA \\ Margareth Afonso Torres ${ }^{1}$, Maria Elisa Hue Moraes²
}

\begin{abstract}
The Nomenclature Committee for Factors of the HLA System of the World Health Organization standardizes the nomenclature of the HLA system and meets regularly during the International Histocompatibility Workshops. During the $15^{\text {th }}$ International Histocompatibility Workshop in Buzios (RJ), Brazil, in September 2008, there was a meeting of the nomenclature committee when new rules were established, which were implemented in April 2010.
\end{abstract}

Keywords: HLA antigens; Systematized medical nomenclature; Histocompatibility

\section{RESUMO}

0 Comitê de Nomenclatura dos Fatores do Sistema HLA da Organização Mundial da Saúde normatiza a nomenclatura do sistema HLA e se reúne regularmente durante os Workshops Internacionais de Histocompatibilidade. Durante o $15^{\circ}$ Workshop Internacional de Histocompatibilidade, em Búzios (RJ), em Setembro de 2008, houve a reunião do comitê de nomenclatura, quando novas regras foram estabelecidas, sendo implantadas em Abril de 2010.

Descritores: Antígenos HLA; Nomenclatura médica sistematizada; Histocompatibilidade

\section{REVIEW OF HLA NOMENCLATURE}

The genes that encode the HLA (human leukocyte antigen) molecules are highly polymorphic and are located in the short arm of chromosome 6, which contains more than 220 protein-encoding genes, most of them related to the immune system.

The First International Histocompatibility Workshop (IHWS), in Durham, North Carolina, USA, in 1964, was dedicated to the serology analysis of reactions obtained with human leukocyte antigens. They seemed to be encoded by two segregating gene series and were, at that time, called LA and FOUR. After analyses of the results of these studies, the need was felt to standardize the nomenclature for the different denominations given to these antigens ${ }^{(1)}$.

At the $3^{\text {rd }}$ IHWS, in Italy, in 1967, the Nomenclature Committee for Factors of the HLA System of the World Health Organization (WHO) was established, which has been responsible since then for standardizing the HLA system and meets regularly during the IHWS events ${ }^{(2)}$.

The first report of HLA specificities was published in 1968, naming the first eight antigens segregated by genes of the system, and was defined, at that time, as $\mathrm{HL}^{(2)}$.

In 1975, during the $6^{\text {th }}$ IHWS, in Denmark, it was established that the HL-A acronym be substituted for HLA.HLA-A and HLA-B substituted the denominations of the two existing loci, LA and FOUR, respectively, and the existence of a third locus called HLA-C was described $^{(3)}$.

During the 1970s and 1980s, the rules for naming HLA antigens were standardized. Their specificities were defined by the prefix HLA, followed by the name of the locus, the letter "w" (from workshop), followed by the digit that defined the antigen (e.g., HLA-Aw24, HLA-Bw51, HLA-Cw1, HLA-DRw1, etc). After confirmation of the specificity, the "w" was abolished, which demonstrated that it was a well-established antigen, accepted as official by the Nomenclature Committee ${ }^{(4-7)}$.

In 1987, rules were introduced for the definition of the alleles identified by molecular methods. The acronym, HLA, was followed by the letter corresponding to the locus in question, inserting the asterisk symbol $\left[{ }^{*}\right]$ (to designate that the method of definition was molecular), followed by the addition of four digits (to name the alleles). The first two digits identified the group of alleles (low resolution, which corresponds to the serological determinant); the third

\footnotetext{
'Division of Histocompatibility, Clinical Pathology Deparment, Hospital Israelita Albert Einstein - HIAE - São Paulo (SP), Brazil.

${ }^{2}$ Immunogenetics Laboratory - LIG, Sao Paulo (SP),Brazil.

Corresponding author: Margareth Afonso Torres - Division of Histocompatibility, Clinical Pathology Deparment, Hospital Israelita Albert Einstein - HIAE - Avenida Albert Einstein, 627/701 - CEP 05651-901 - São Paulo (SP), Brasil - Tel.: (11) 2151 - 2112 - e-mail: margaretht@einstein.br

Conflict of interest: none

Received on: Oct 21, 2010 - Accepted on: Apr 16, 2011
} 
and fourth digits defined the specificity of the allele (in high resolution $)^{(8,9)}$.

In 1990, the fifth and sixth digits were introduced, naming silent mutations caused by the substitution of nucleotides that did not result in protein alteration. The seventh and eighth digits indicate mutations that occur outside the gene encoding regions ${ }^{(10)}$.

In 1991, after definition of alleles by molecular methods and the correlation with serological specificities, the letter "w" was abolished from antigens encoded by HLA loci, leaving only those of the HLA-C locus in order to differentiate them from the nomenclature of genes of the complement system ${ }^{(10)}$.

The form of expression of certain alleles is signaled by the introduction of additional suffixes. The suffix $\mathrm{N}$ (null) indicates null alleles, genes that do not encode protein products; L (low) indicates that the gene encodes a low-expression protein; S (secreted) encodes a molecule found in the soluble form and which is not expressed on cell surface; $\mathrm{C}$ (cytoplasm) is used when the products are expressed in cytoplasm; A (aberrant) when there is doubt as to where the expression occurs; and Q (questionable) indicates that it is uncertain and yet without a definition as to whether the mutation generates a modification in expression $^{(11-14)}$.

In 2002, due to a constant increase in the number of alleles, the situation reached a point at which alleles from groups HLA-A*02 and HLA-B*15 surpassed the total of 99 , and as per the existing rules of nomenclature, a third decimal place could not be considered in these cases, since the third and fourth decimal places were used to define a high-resolution allele. In face of this situation, it was decided to name them HLA-A*9201 and $-\mathrm{B}^{*} 9501$, respectively ${ }^{(15)}$. In 2008, the same situation arose for more than 15 allele groups, and changes in nomenclature rules became crucial.

During the $15^{\text {th }}$ IHIWS in September 2008, in Buzios $(\mathrm{RJ})$, Brazil, there was a meeting of the nomenclature Committee and new rules were drawn up, which were then implemented in April 2010 ${ }^{(16)}$. The primary modifications are as follows:

1. Expansion of the names was obtained by the introduction of separators used to divide: the group of alleles; its specificity; the silent mutation; variations of the intron. All alleles are named with at least four digits. The two digits before the first separator describe the groups of alleles, which generally correspond to the antigens determined by serological methods: low-resolution. Next, alleles defined by high-resolution received sequencial numbers corresponding to their different sequences, numbered according to the order in which they were discovered. It was also established that, as of April 2010, suffixes "A" ("aberrant") and "C" ("cytoplasm") would no longer be used to express the alleles.

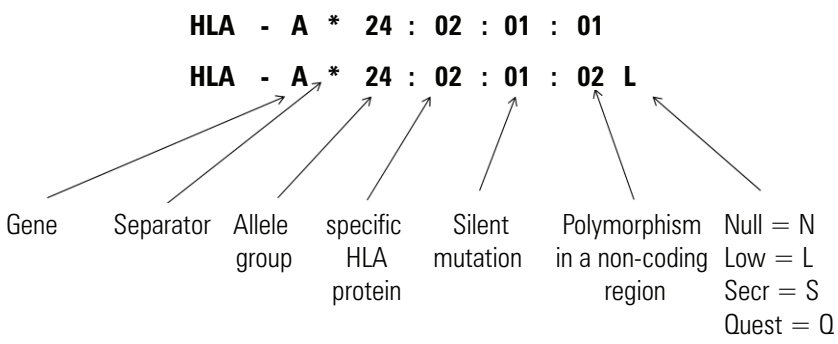

2.Alleles HLA-A*92 and -B*95 were renamed, using the new rules, as per the following example:
A*9201
$A^{*} 9202$
B*9501
B*9502

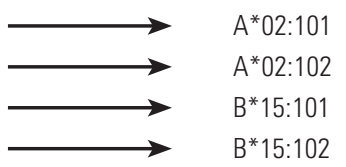

3.Alleles DPB1 were renamed, as per the following examples:

\begin{tabular}{|c|c|}
\hline DPB1*010101 & DPB1*01:01:01 \\
\hline DPB1*020102 & $\mathrm{DPB}^{*}{ }^{*} 02: 01: 02$ \\
\hline DPB1*0202 & $\mathrm{DPB} 1{ }^{*} 02: 02$ \\
\hline DPB1*030101 & DPB1*03:01:01 \\
\hline DPB1*9901 & DPB1*99:01 \\
\hline DPB1*0102 & DPB1*100:01 \\
\hline DPB1*0203 & DPB1*101:01 \\
\hline $\mathrm{DPB} 1 * 0302$ & DPB1*102:01 \\
\hline $\mathrm{DPB} 1{ }^{*} 0204$ & DPB1*103:01 \\
\hline
\end{tabular}

4. The $\mathrm{w}$ of alleles of the $\mathrm{C}$ locus was dropped, but continues in the denomination of the antigens in order to distinguish them from complement system factors and KIRs (killer-cell immunoglobulin-like receptors) ligands, $\mathrm{C} 1$ and $\mathrm{C} 2$. Thus:

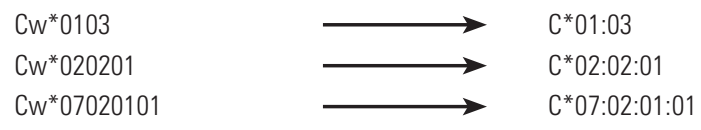

5.Exons 2 and 3 encode the domains alpha 1 and 2 of HLA molecules class I, and Exon 2 encodes the beta 1 domain of HLA molecules class II, forming a peptide binding gap. The differences found in the various alleles outside of this region are not considered relevant in the selection of receptor and donor pairs with the purpose of hematopoietic progenitor cell transplants. 
To define this type of ambiguity, codes $P$ and $G$ were created. Code $\mathrm{P}$ is used for alleles with nucleotide sequences which, albeit different, result in the same coding as the sequence of the protein for the antigen recognition site (ARS). This group of alleles is designated with the first two fields of the smaller number of the allele group followed by a capital $\mathrm{P}$ letter. For example, the following group is called HLA-A*02:01P:

$\mathrm{A} * 02: 01: 01: 01 / \mathrm{A} * 02: 01: 01: 02 \mathrm{~L} / \mathrm{A}^{*} 02: 01: 01: 03 /$ A*02:01:02/A*02:01:03/A*02:01:04/A*02:01:05/ $\mathrm{A}^{*} 02: 01: 06 / \mathrm{A} * 02: 01: 07 / \mathrm{A}^{*} 02: 01: 08 / \mathrm{A} * 02: 01: 09 /$ A*02:01:10/A*02:01:11/A*02:01:12/A*02:01:13/ A*02:01:14/A*02:01:15/A*02:01:17/A*02:01:18/ A*02:01:19/A*02:01:21/A*02:01:22/A*02:01:23/ A*02:01:24/A*02:01:25/A*02:01:26/A*02:01:27/ A*02:01:28/A*02:01:29/A*02:01:30/A*02:01:31/ A*02:01:32/A*02:01:33/A*02:01:34/A*02:01:35/ A*02:01:36/A*02:01:37/A*02:01:38/A*02:01:39/ A*02:01:40/A*02:01:41/A*02:01:42/A*02:09/A*02:66/ $\mathrm{A}^{* 02: 75 / \mathrm{A} * 02: 89 / \mathrm{A}^{*} 02: 97: 01 / \mathrm{A}^{*} 02: 97: 02 / \mathrm{A} * 02: 132 /}$ $\mathrm{A}^{*} 02: 134 / \mathrm{A}^{*} 02: 140$.

The $\mathrm{G}$ code is used for alleles that possess the same nucleotide sequence for the ARS-encoding exons. As was exemplified earlier, the first three fields of the allele with the lowest number of the group that satisfies this condition are followed by the capital "G" letter, and can be summarized as HLA-A*02:01:01G:

$A * 02: 01: 01: 01 / A * 02: 01: 01: 02 L / A * 02: 01: 01: 03 /$ A*02:01:08/A*02:01:11/A*02:01:14/A*02:01:15/ A*02:01:21/A*02:09/A*02:43N/A*02:66/A*02:75/ A*02:83N/A*02:89/A*02:97:01/A*02:97:02/A*02:132/ $\mathrm{A}^{*} 02: 134 / \mathrm{A}^{*} 02: 140$

The full list of alleles with the old and new nomenclature is available at the IMGT/HLA database (www.ebi.ac.uk/imgt/hla).

The official sequences of all HLA system specificities can be found at the database of IMGT/HLA (www.ebi. ac.uk/imgt/hla) and of the Anthony Nolan Bone Marrow Trust (www.anthonynolan.org).

The new alleles are published in the journals Tissue Antigens, Human Immunology, and International
Journal of Immunogenetics, and may also be accessed directly at the IMGT/HLA previously described.

In July 2010, the latest version was updated, and includes 5,302 HLA alleles at IMGT/HLA (http://hla. alleles.org/nomenclature/index.html).

\section{REFERENCES}

1. Histocompatibility Testing 1965. Report of a Conference and Workshop Sponsored by the Boerhaave Courses for Postgraduate Medical Education. University of Leiden Aug 15-21, 1965. p.283.

2. Nomenclature for factors of the HL-a system. Bull World Health Organ. 1968;39(3):483-6.

3. Nomenclature for factors of the HL-A system. Bull World Health Organ. 1972;47(5):659-62.

4. Nomenclature for factors of the HLA system. Bull World Health Organ. 1975;52(3):261-5

5. Nomenclature for factors of the HLA system, 1977. Bull World Health Organ. 1978;56(3):461-5

6. Nomenclatureforfactors of the HLA system. In: TerasakiPI, editor. Histocompatibility testing. Los Angeles: UCLA Tissue Typing Laboratory; 1980. p.18-20

7. Nomenclature for factors of the HLA system. In: Albert ED, Baur MP, Mayr WR, editors. Histocompatibility testing. Berlin: Springer-Verlag;1984. p. 4-8.

8. Nomenclature for factors of the HLA system, 1987.Tissue Antigens.1988;32(4):177-87.

9. Bodmer WF, Albert E, Bodmer JG, Dupont B, Mach B, Mayr WR, et al. Nomenclature for factors of the HLA system, 1987. In: Dupont B, editor. Immunobiology of HLA. New York: Springer-Verlag; 1989. p. 72-9.

10. Bodmer JG, Marsh SG, Albert E, Bodmer WF, Dupont B, Erlich HA, et al. Nomenclature for factors of the HLA system, 1991. In: Tsuji T, Aizawa M, Sasazuki T, editors. HLA1991. Oxford: Oxford University Press; 1992. p. 17-31.

11. Bodmer JG, Marsh SG, Albert ED, Bodmer WF, Dupont B, Erlich HA, et al. Nomenclature for factors of the HLA system, 1994. Tissue Antigens.1994;44(1):1-18.

12. Bodmer JG, Marsh SG, Albert ED, Bodmer WF, Bontrop RE, Charron D, et al. Nomenclature for factors of the HLA system, 1995. Tissue Antigens.1995;46(1):1-18.

13. Bodmer JG, Marsh SG, Albert ED, Bodmer WF, Bontrop RE, Charron D, et al. Nomenclature for factors of the HLA system, 1996. Tissue Antigens.1997; 49(3Pt2):297-321.

14. Bodmer JG, Marsh SG, Albert ED, Bodmer WF, Bontrop RE, Dupont B, et al. Nomenclature for factors of the HLA system, 1998. Tissue Antigens.1999;53(4Pt2):407-46.

15. Marsh SG, Albert ED, Bodmer WF, Bontrop RE, Dupont B, Erlich HA, et al. Nomenclature for factors of the HLA system, 2002. Tissue Antigens. 2002;60(5):407-64.

16. Marsh SG, Albert ED, Bodmer WF, Bontrop RE, Dupont B, Erlich HA,et al. Nomenclature for factors of the HLA system, 2010.Tissue Antigens. 2010;75(4):291-455. 